2. Дудчик М. В. Принципи лікування хронічного запального процесу додатків матки. Жіночий лікар. 2007. № 1, С. 8-12.

3. Ночвіна О. А. Патогенетичні аспекти формування синдрому хронічного тазового болю у жінок репродуктивного віку. Wschodnioeuropejskie Czasopismo Naukowe. 2016. № 7, Ч. 1. C. 65-71.

DOI https://doi.org/10.30525/978-9934-26-182-4-9

\title{
EXPERIENCE OF THE USE OF CALCITONIN GENE-RELATED PEPTIDE DEFINITION IN THE DIFFERENTIAL DIAGNOSIS OF MIGRAINE AND CERVICOGENIC HEADACHE
}

\author{
Dubenko O. E. \\ Doctor of Medical Sciences, \\ Professor at the Department of Neurosurgery, \\ Neurology and Reflexotherapy \\ Kharkiv Medical Academy of the Postgraduate Education \\ Marchenko V. G. \\ Doctor of Medical Sciences, \\ Professor at the Department of Neurosurgery, \\ Neurology and Reflexotherapy \\ Kharkiv Medical Academy of the Postgraduate Education \\ Chernenko A. G. \\ Applicant of phD at the Department of Neurosurgery, \\ Neurology and Reflexotherapy \\ Assistant at the Department of Clinical Informatics and Information \\ Technologies in Health Care Management \\ Kharkiv Medical Academy of the Postgraduate Education \\ Kharkiv, Ukraine
}

Migraine is the most common neurological disease that significantly affects a person's health and ability to work [1]. It is often accompanied by comorbidities and co-occurring conditions. Patients with migraine have a high frequency of myofascial pain syndrome of head and neck muscles [2, 3, 4]. Differential diagnosis of migraine and cervicogenic headache is complicated by a significant combination of symptoms. 
The close relationship between trigeminovascular system and trigeminocervical complex provides common symptoms of migraine and cervicogenic headache, such as hemilateral headache, nausea, and sometimes vomiting at the peak of headache, photophobia, pain and tension in the muscles of the head and neck.

Diagnostic criteria for migraine are based on the clinical characteristics of the disease and the exclusion of other causes of headache. Diagnosis of cervicogenic headache in clinical practice is carried out using invasive methods (diagnostic blockades) and provocative maneuvers [5].

Recent decades have shown that the calcitonin gene-related peptide (CGRP) plays a key role in the pathophysiology of migraine [6, 7].

The aim is to study the diagnostic value of the plasma level of calcitonin gene-related peptide (CGRP) in the differential diagnosis of migraine with concomitant neck pain and pericranial muscle tension and cervicogenic headache.

Methods and subjects. 112 patients ( 84 women, 28 men) aged from 18 to 58 years were involved in the study. 77 patients were diagnosed with episodic migraine (with a typical aura in 17 and without aura in 60 patients), 35 people had cervicalgia with muscular-tonic syndromes and cervicogenic headache.

Among the patients with migraine, 42 had concomitant cervicalgia with muscular-tonic dysfunction of the cervical-shoulder region. The examined patients were divided into 3 clinical groups: I - episodic migraine with concomitant cervicalgia, II - episodic migraine without neck pain, III cervicogenic headache.

The intensity of the headache attack was assessed using the visual analog scale, the effect of migraine on daily activity and performance using the MIDAS and HIT-6 scales $[8,9]$. Neck Disability Index scale was used to assess the impact of neck pain on the patient's life limitations [10]. The control group for comparing the serum level of CGRP consisted of 30 clinically healthy persons. The level of CGRP was determined in blood plasma by enzyme-linked immunosorbent assay using the sandwich ELISA principle (Elabscience ${ }^{\circledR}$ Human CGRP1 (Calcitonin Gene Related Peptide 1) ELISA Kit, USA).

Results. In the group of patients with a combination of episodic migraine with cervicalgia compared to the group with isolated migraine, the number of days with headache over the last 3 months was higher $(p=0.000052)$, the effect of headache on daily activity performance according to the MIDAS and HIT -6 scales was more significant $(\mathrm{p}=0.000482 ; \mathrm{p}=0.000001)$, and the number of combined analgesics used was higher $(\mathrm{p}=0.000003)$ 
Plasma level of CGRP was statistically significantly higher in patients with episodic migraine compared with the group with cervicalgia without migraine $(\mathrm{p}=0.012543)$, in which it did not differ from the control.

The highest levels of CGRP in blood plasma were observed in group I (episodic migraine with cervicalgia) $-242.98 \pm 5.08 \mathrm{pg} / \mathrm{ml}$, in group II (episodic migraine without concomitant cervicalgia) this level was lower -145 , $82 \pm 15.38 \mathrm{pg} / \mathrm{ml}$, the difference was statistically significant $(\mathrm{p}=0.000341)$. The levels of CGRP in blood plasma in group III (cervicogenic headache) were statistically significantly lower than in patients in groups I and II $-51.96 \pm 4.46$ $\mathrm{pg} / \mathrm{ml}(\mathrm{p}=0.000002$ for group I, $\mathrm{p}=0.012543$ for group II) and did not differ from the control group $-51,48 \pm 5,08 \mathrm{pg} / \mathrm{ml}(\mathrm{p}=1,000000)$. (Fig. 1).

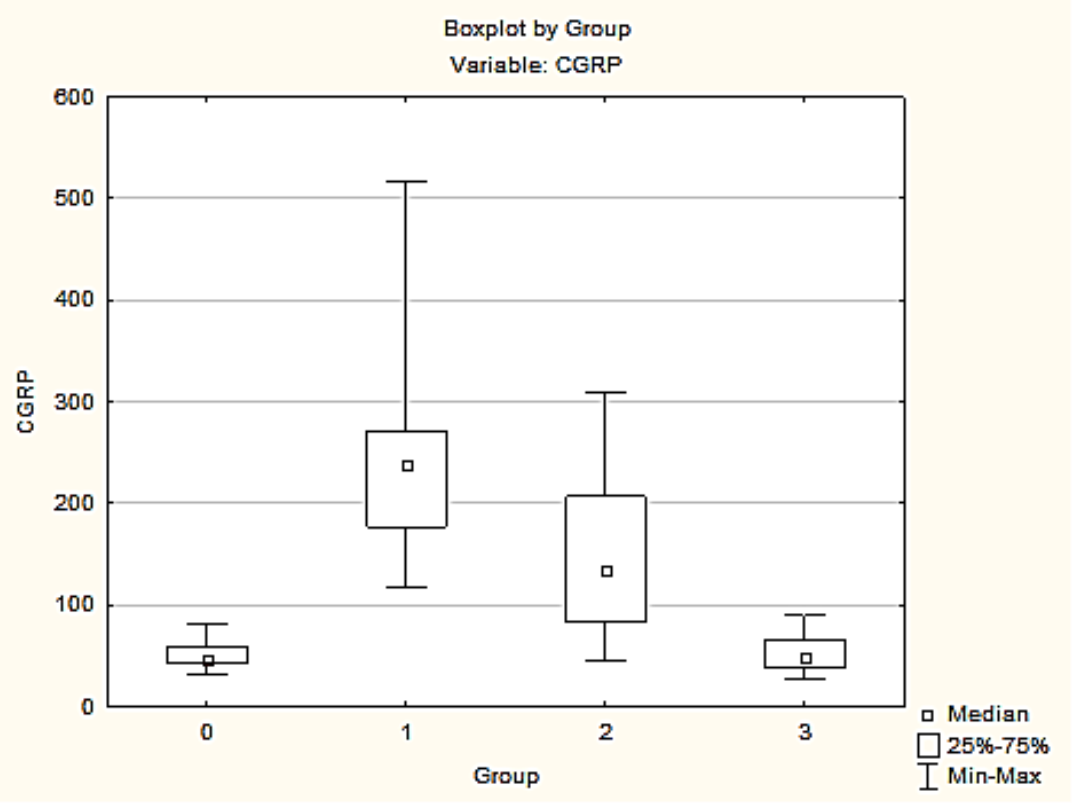

Fig. 1. Median and interquartile range of plasma CGRP levels in patients of the different study groups 
The CGRP level was statistically significantly higher in women with migraine (166.45 \pm 13.28$)$ compared to men $(144.89 \pm 11.42, \mathrm{p}=0.000035)$, but did not differ in migraine with and without aura $(\mathrm{p}=0.3226)$.

\section{Conclusions.}

The levels of CGRP in blood plasma in patients with episodic migraine are significantly higher than in clinically healthy people and in patients with cervicogenic headache. This confirms its importance as a reliable laboratory biomarker of migraine.

Plasma CGRP levels were slightly higher in patients with a combination of episodic migraine with cervicalgia and cervicogenic headache than in patients with isolated migraine. This may indicate increased sensitization and be a risk factor for chronic migraine.

Determination of plasma CGRP may be a useful additional biomarker for the differential diagnosis of migraine with other forms of both primary and secondary headache, which will also improve individual treatment of both acute headache and prevention tactics.

The presence of concomitant cervicalgia in patients with episodic migraine significantly affects the plasma CGRP level and the course of the disease (increase in the number of days with headache, the number of analgesics taken, reduced work efficiency and daily activity).

\section{References:}

1. Burch R.C., Buse D.C., Lipton R.B. Migraine: Epidemiology, Burden, and Comorbidity. Neurol Clin. 2019 Nov. Vol.37(4). P.631-649. doi: 10.1016/j.ncl.2019.06.001. Epub 2019 Aug 27.PMID: 31563224.

2. Buse D.C., Greisman J.D., Baigi K., Lipton R.B. Migraine progression: a systematic review. Headache. 2019. 59:306-338. https://doi.org/10.1111/head.13459;

3. Florencio L.L., Ferracini G.N., Chaves T.C. et al. Active trigger points in the cervical musculature determine the altered activation of superficial neck and extensor muscles in women with migraine. Clin J Pain. 2017. 33:238-245.;

4. Loder E., Burch R. Measuring pain intensity in headache trials: which scale to use? Cephalalgia, 2012, 32(3) 179-182.

5. Headache Classification Committee of the International Headache Society (IHS) The International Classification of Headache Disorders, 3rd edition // Cephalalgia. - 2018 Jan. - Vol. 38 (1). - P. 1-211. doi: 10.1177 / 0333102417738202. PMID: 29368949. 
6. Dubenko O.Ye. Calcitonin Gene-Related Peptide in migraine: the pathigenetic factor and therapeutic target (review) // International Neurological Journal. - 2018. - №2(96). - P.71-77. doi:10.22141/22240713.2.96.2018.130481.

7. Fan P.C., Kuo P.H., Lee M.T., Chang S.H., Chiou L.C. Plasma Calcitonin Gene-Related Peptide: A Potential Biomarker for Diagnosis and Therapeutic Responses in Pediatric Migraine // Front Neurol. - 2019 Jan 24; 10: 10. doi: 10.3389 / fneur.2019.00010. PMID: 30733702; PMCID: PMC6353836.

8. Stewart W.F., Lipton R.B., Kolodner K.B., Sawyer J., Lee C., Liberman J.N. Validity of the Migraine Disability Assessment (MIDAS) score in comparison to a diary-based measure in a population sample of migraine sufferers // Pain. - 2000 Oct. - Vol. 88 (1). P. 41-52. doi: 10.1016 / S0304-3959 (00) 00305-5. PMID: 11098098.

9. Yang M., Rendas-Baum R., Varon S.F., Kosinski M. Validation of the Headache Impact Test (HIT $-6^{\mathrm{TM}}$ ) across episodic and chronic migraine // Cephalalgia: an international journal of headache. - 2011. - Vol. 31 (3). P. 357-367. https://doi.org/10.1177/0333102410379890.

10. Vernon H, Mior S. The Neck Disability Index: a study of reliability and validity. J Manipulative Physiol Ther. 1991 Sep;14(7):409-15. Erratum in: J Manipulative Physiol Ther 1992 Jan;15(1):followi. PMID: 1834753. 